\title{
KEPEMIMPINAN KARISMATIK DAN KEPEMIMPINAN YANG MELEMBAGA PADA MASA PERJANJIAN LAMA DAN DEWASA INI
}

\author{
Christian Gossweiler \\ Gereja Pastor Dr. Christian Goßweiler in the Protestant Church in Eutingen Jerman \\ christian.pebri.gossweiler@gmail.com
}

\begin{abstract}
The judges of Israel (as described in the biblical book of Judges) had not only judicial functions; they were the leaders of the people. Their leadership can be described as a charismatic leadership: Firstly, they became leaders just by their God-given charisma and military success, not by any institutional mechanism, such as public vote, dynastical succession etc. Secondly, the judges ruled without any institutional basis, they had no capital city, no palace, no bureaucracy or public administration, no tax system, no standing army and no privileges as leaders. They gained their military victories by general draft of all Israelites (usually poorly armed) and very often by the terror of God, which overwhelmed their enemies as some kind of communal frenzy. Thus the power of God was very directly felt by the Israelites, which made them turn back to Yahweh, their God, whom they had forsaken. That is why George Pixley categorizes the reign of the judges as a theocracy or even as the Kingdom of God. But whenever a judge died, there was no mechanism of succession, which usually lead to a political and religious crisis after the death of most judges. Therefore the Israelites finally opted for monarchy as a more steady and institutionalized form of leadership, with a clear dynastical mechanism of succession, a professional army and professional public administration. The Israelites paid the price for this stable leadership in the form of taxes, forced labour and partly loss of their freedom. This article compares the leadership of judges as a model of charismatic leadership and the monarchy as a model of the institutionalized form of leadership.
\end{abstract}

Keywords: charismatic leadership; Judges; leadership institutions; monarchy

\section{Pendahuluan}

Bangsa Israel di Perjanjian Lama mengalami setidak-tidaknya dua macam pola kepemimpinan: Kepemimpinan hakim-hakim selama 300 tahun lebih (1382-1012 s.M. ${ }^{1}$, seperti diceritakan di kitab Hak., 1Sam. 1-12, Rut) serta kepemimpinan raja-raja selama 425 tahun (1012-587 s.M.- seperti diceritakan di 1Sam. 13 s.d. 2Taw. 36). Sebutan "hakim" dan sebutan "raja" bukan sekadar dua istilah bagi seorang pemimpin, melainkan

\footnotetext{
${ }^{1}$ Payne, J. P. . Art. "Book of Judges", dalam Marshall, I. Howard; Millard, A. R.; Packer, J. I.; Wiseman, D. J. (eds.). New Bible Dictionary, 3rd ed. (Leicester, England: Inter-Varsity Press, 1996): 630-631.
} 
menunjukkan dua pola kepemimpinan yang berbeda secara prinsip. Manakah yang lebih baik di antara dua pola kepemimpinan tersebut? Ketika bangsa Israel menghendaki kepemimpinan raja, keinginan itu sepertinya dianggap jahat oleh Tuhan, sehingga Tuhan berfirman kepada Samuel: "bukan engkau yang mereka tolak, tetapi Akulah yang mereka tolak, supaya jangan Aku menjadi raja atas mereka" (1Sam. 8:7). Namun, kondisi bangsa Israel pada zaman hakim-hakim digambarkan buruk juga, dengan dua kisah contoh di Hakim-Hakim 17-21, yang disimpulkan dengan penilaian negatif sebagai ayat penutup di kitab Hakim-hakim: "Pada zaman itu tidak ada raja di antara orang Israel; setiap orang berbuat apa yang benar menurut pandangannya sendiri” (Hak. 21:25). Jadi, uraian eksegetis berikut ini akan memaparkan unsur karismatik dalam kepemimpinan hakimhakim dan unsur kelembagaan dalam kepemimpinan raja serta segi baik dan segi buruk dari dua pola kepemimpinan tersebut serta relevansinya untuk kepemimpinan dewasa ini.

\section{Kepemimpinan Hakim-Hakim}

Pada zaman hakim-hakim orang Israel memiliki pola kepemimpinan karismatik: Para hakim dibangkitkan dan diberi karisma kepemimpinan oleh Tuhan, terkadang atas doa umat Israel, seperti diceritakan misalnya di Hakim-Hakim 3:9 "Lalu berserulah orang Israel kepada Tuhan, maka Tuhan membangkitkan seorang penyelamat bagi orang Israel, yakni Otniel, anak Kenas adik Kaleb. Roh Tuhan menghinggapi dia, dan ia menghakimi orang Israel. Ia maju berperang, lalu Tuhan menyerahkan Kusyan-Risyataim, raja Aram, ke dalam tangannya, sehingga ia mengalahkan Kusyan-Risyataim. Jadi, dalam penetapan seorang hakim tidak ada unsur pemilihan oleh rakyat, tidak ada unsur dinasti, unsur upacara peneguhan atau unsur konstitusional lainnya. Seorang hakim diikuti dan ditaati oleh rakyat hanya oleh karena rakyat mengakui karisma ilahi yang ada pada hakim itu.

Hakim terpilih diberikan karisma oleh Tuhan secara khusus untuk memimpin bangsa Israel dalam peperangan. Dalam peperangan itu bangsa Israel belum mempunyai tentara yang tetap, melainkan para petani Israel mengangkat senjata "ala kadarnya" untuk melawan musuhnya seperti sabit, cangkul dsb. Mereka belum memiliki pedang dari besi, karena pada masa hakim-hakim masih merupakan masa peralihan dari Zaman Perunggu ke Zaman Besi. Di 1Sam. 13:19 dicantumkan: "Seorang tukang besi tidak terdapat di seluruh negeri Israel, sebab orang Filistin berkata: "Jangan-jangan orang Ibrani membuat pedang atau tombak". Jadi, orang Israel tidak boleh atau tidak sanggup membuat senjata atau alat lain dari besi. Menurut penemuan arkeologi, orang Israel memang sudah memiliki 
beberapa alat dari besi ${ }^{2}$, tetapi kemungkinan besar mereka belum memproduksinya sendiri. Sedangkan orang Kanaan sudah memiliki banyak kereta besi dan senjata besi lainnya (Hak. 1:19), meskipun belum sanggup mengelola besi menjadi baja. Jadi, orang Filistin dan orang Kanaan sudah hidup di Zaman Besi, sedangkan orang Israel masih hidup di Zaman Perunggu. Namun, orang Israel secara ajaib ditolong oleh kedahsyatan Tuhan yang menakuti dan mengacaukan musuh mereka, hingga terjadi semacam kegilaan massal (Hak. 8:12; 4:15-16; band. Yos. 2:9; 24:12; Ul. 2:25; 4:34; 7:20; 11:25). Dalam hal penyerangan malam Gideon, kekacauan itu mungkin ada juga unsur psikis, tetapi bagaimana pun Tuhan-lah yang "membuat pedang seorang diarahkan kepada yang lain" di antara musuh-musuh Israel (Hak. 7:22). Kedahsyatan Tuhan itu adalah senjata ajaib yang memberi kemenangan kepada bangsa Israel.

Dengan demikian orang Israel sendiri sungguh merasakan kuasa Tuhan, setiap kali Tuhan membangkitkan seorang hakim dan memberi kemenangan melalui hakim itu. Lalu umat Israel kembali menyembah Tuhan yang sebelumnya ditinggalkan. Selain dari itu, beberapa hakim juga berjuang aktif untuk menghapus penyembahan berhala di Israel (mis. Hak. 6:25-32). Tetapi para hakim tidak membangun birokrasi, tidak membangun ibu kota, tidak memiliki istana/ privilegia (hak istimewa) lainnya. Para hakim hanya melaksanakan fungsi sebagai pemimpin saja. Selain fungsi sebagai pemimpin perang, mereka juga menyelesaikan perkara pengadilan. Maka mereka disebut $s^{h} o p^{h} e t$ (bhs. Ibrani: hakim), meskipun fungsinya tidak terbatas pada perkara pengadilan saja.

Namun setelah hakim itu meninggal, tidak ada mekanisme pergantian pemimpin, sehingga orang Israel mengalami suatu krisis, mereka harus hidup tanpa pemimpin untuk sementara waktu, tidak merasakan kuasa Tuhan lagi, dan kembali menyembah berhalahingga Tuhan membangkitkan lagi seorang hakim bagi mereka. Dengan demikian campur tangan Tuhan sangat terasa dalam corak kepemimpinan para hakim, karena Tuhan yang membangkitkan para hakim. Menurut penilaian 1 Samuel 8:7 pada zaman hakim Tuhanlah yang menjadi raja atas orang Israel, dan sampai sekarang banyak ahli menyebutkan corak kepemimpinan pada zaman hakim sebagai teokrasi ${ }^{3}$, yaitu pemerintahan oleh Tuhan sendiri sebagai raja. Teokrasi/ pemerintahan Tuhan sebagai raja tidak berarti bahwa Tuhan memerintah secara langsung, misalnya dengan mengirim perintah dari surga ke bumi.

\footnotetext{
${ }^{2}$ Lih. Uta Zwingenberger, Art. „Eisenzeit I“ (bhs. Jerman: Zaman Besi I), dalam: WibiLex Wissenschaftliche Bibellexikon im Internet (bhs. Jerman: Leksikon Alkitab di Internet) ditulis Febr. 2007. Lihat: https://www.bibelwissenschaft.de/stichwort/17088/, diakses 30 Okt. 2019.

${ }^{3}$ George V. Pixley: Kerajaan Allah . Artinya bagi Kehidupan Kultus, Politis, Ideologis dan Kemasyarakatan (Jakarta: BPK, 1990), 17.
} 
Teokrasi pada zaman hakim-hakim juga bukan pemerintahan imam-imam. Melainkan Tuhan memerintah dengan cara memberi karisma kepada hakim-hakim dan memberi kemenangan ajaib dalam peperangan.

Dari segi lain, pemerintahan hakim amat kurang stabil dari segi politik, agama dan hukum: Ketika tidak ada hakim, orang Israel menyembah berhala, dikalahkan oleh musuh dan terjadilah juga banyak kekacauan moral, seperti disimpulkan di Hakim-Hakim 17:6; 21:25: "Pada zaman itu tidak ada raja di antara orang Israel; setiap orang berbuat apa yang benar menurut pandangannya sendiri”. Dari segi politik, bangsa Israel belum menguasai seluruh Tanah Perjanjian, masih ada banyak kantong-kantong bangsa lain di tengah wilayah Israel (Hak. 1). Bangsa-bangsa Kanaan menguasai dataran-dataran, sedangkan bangsa Israel hidup di bukit-bukit dan gunung-gunung. Justru dengan pemerintahan yang tidak stabil tersebut, orang Israel merasa sungguh tergantung dari pertolongan Tuhan. Bagaimanapun, sistem pemerintahan hakim yang demikian dapat bertahan sekitar 200-400 tahun.

Sebenarnya Abimelekh sudah pernah mencoba beralih dari pemerintahan hakim ke pemerintahan raja (monarki), ia ingin menjadi raja di Israel, tetapi usaha itu gagal (Hak. 9). Baru pada abad ke-10 s.M. orang Israel ingin memiliki "seorang raja ..., seperti pada segala bangsa-bangsa lain” (1 Sam. 8:5,20). Dengan kata lain, orang Israel menganggap sistem monarki yang dipakai oleh bangsa-bangsa Kanaan lebih stabil daripada kepemimpinan karismatik melalui hakim-hakim. Mereka menginginkan kemapanan dan tidak mau lagi tergantung dari seorang pemimpin karismatik yang harus dibangkitkan oleh Tuhan, mereka juga tidak ingin lagi hanya tergantung pada kedahsyatan Tuhan dalam peperangan mereka. Mungkin juga kelemahan religius dan kelemahan hukum dalam pemerintahan para hakim semakin disadari, apalagi ketika anak-anak Samuel menjadi hakim yang kurang baik (1 Sam. 8:1-3).

\section{Kepemimpinan Raja-Raja}

Orang Israel menginginkan kemapanan di bawah pemerintahan seorang raja, dengan tugas yang tidak berbeda dari tugas seorang hakim, seorang raja yang "menghakimi kami dan memimpin kami dalam perang" (1 Sam. 8:20; band. ay 7). Kata kerja "menghakimi" pun (Ibr. $s^{h} a p^{h} a t$ ) masih satu akar dengan kata benda "hakim" (bhs. Ibrani: $\left.s^{h} p^{h} e t\right)$. Demikian pula Saul sebagai raja pertama memang bergelar raja, dan diurapi sebagai raja. Tetapi corak kepemimpinan Saul masih sama dengan para hakim: Ia 
belum memiliki istana atau ibu kota, ia belum memiliki pegawai, ia baru mempunyai seorang panglima dan mulai membangun pasukan tentara tetap (1Sam. 14:50-52). Saul memang dinobatkan sebagai raja (1Sam. 10:17-24), tetapi lebih-lebih lagi ia menjadi pemimpin oleh karena karisma dan keberhasilannya mengalahkan orang Amon, seperti para hakim sebelumnya. Baru setelah karisma Saul dibuktikan dan diakui oleh rakyat, "pergilah seluruh bangsa itu ke Gilgal dan menjadikan Saul raja di sana di hadapan Tuhan di Gilgal" (1Sam. 11:15). Sama seperti pada zaman hakim-hakim, demikian pula pada zaman Saul kedahsyatan Tuhan masih menjadi senjata ajaib bagi bangsa Israel (1Sam. 14:20). Seperti lazimnya bagi seorang raja, Saul berusaha membangun dinasti, tetapi usaha itu gagal. Yonatan bin Saul tidak pernah menjadi raja, Isyboset bin Saul pun hanya dapat memerintah dalam kurun waktu yang singkat saja (2Sam. 2:8-4:7).

Daud pun masih bangkit sebagai seorang pemimpin karismatik, seperti para hakim saat dulu. Namun, Daud dari awal mengumpulkan pasukan tentara sendiri yang loyal kepadanya. Dengan laskar itu, ia merebut kota Yerusalem yang menjadi ibu kota milik Daud dengan istana Daud di dalamnya. Dari Yerusalem, ia mulai membangun aparat pemerintahan yang semakin teratur dan bahkan mengangkat imam besar (2Sam. 8:15-18; 20:23-26). Tetapi sekali-sekali Daud masih memanggil seluruh orang Israel menjadi pasukannya dan bukan hanya laskar bayarannya saja (2Sam. 11:1). Maka dalam pemerintahan Daud, ciri pemerintahan hakim masih nampak sedikit. Perlu dicatat pula bahwa baik Saul maupun Daud dipilih oleh para penatua dan rakyat (1Sam. 11:15; 2Sam. 2:4; 5:3). Sehingga sangat mungkin bahwa pada awalnya orang Israel belum membayangkan pemerintahan raja yang diwariskan dalam satu dinasti, melainkan monarki di mana raja dipilih oleh rakyat atau paling tidak oleh tua-tua (elective monarchy, sama dengan bentuk monarki yang dewasa ini masih ada di Malaysia dan di Uni Emirat Arab). Mungkin tradisi ini kemudian hari dipelihara di Kerajaan Israel Utara, di mana memang ada dinasti-dinasti raja, tetapi dinasti-dinasti itu umumnya tidak bertahan lama. Namun, sistem pemerintahan raja elektif itu ternyata kurang stabil.

Raja Salomo naik takhta melalui "jalur dinasti", ia mendirikan pemerintahan yang semakin mantap, sistem perpajakan yang semakin kuat, hubungan ekonomi dengan pelbagai negara, pasukan bayaran yang semakin profesional dengan pasukan kereta, dan ia menikmati kehidupan mewah di istana yang dibangunnya sebagai hak istimewa raja. Kehidupan agama pun menjadi semakin mapan di Bait Suci yang dibangun raja Salomo. Tuhan pun memberi janji bahwa monarki Daud dan Salomo akan "kokoh untuk 
selamanya" (2Sam. 7:16). Kerajaan Daud yang abadi itu dilanjutkan oleh Yesus Kristus, meskipun dalam bentuk yang lebih rohani.

Memang, sesudah kematian Salomo kerajaan pecah menjadi kerajaan Yehuda di Selatan dan kerajaan Israel di Utara. Tetapi setidak-tidaknya di kerajaan Yehuda monarki dan dinasti Daud-Salomo bertahan selama empat ratus tahun lebih, hingga kerajaan itu diruntuhkan oleh tentara Babel pada tahun 587 s.M. Dengan pasukan yang profesional tersebut, raja-raja Israel dan Yehuda terkadang kalah dan menang, tetapi senjata ajaib dalam bentuk kedahsyatan Tuhan semakin sukar dirasakan (2Taw. 20:20-24). Kedahsyatan Tuhan seperti itu justru dialami ketika takhta raja diduduki oleh pemimpin karismatik, seperti misalnya Yosia dan Yosafat. Meskipun mereka naik takhta, menurut peraturan lembaga (sebagai ahli waris takhta), mereka ternyata memiliki karisma juga. Jadi, kepemimpinan yang melembaga pasti memiliki mekanisme pergantian pemimpin-entah diganti dengan pemimpin yang berkarisma, entah posisi pemimpin diisi dengan pemimpin yang kurang berkarisma (terutama kalau pemimpin yang berkarisma tidak ditemukan). Dalam hal ini kepemimpinan yang melembaga mengikuti prinsip: Daripada tidak ada pemimpin sama sekali, lebih baik ada pemimpin meskipun kurang berkarisma.

Jadi peralihan dari pemerintahan hakim ke sistem monarki terjadi secara bertahap: Saul adalah seorang hakim yang berlagak sebagai raja, Daud adalah seorang raja yang masih sesekali berlagak sebagai hakim, dan barulah Salomo yang benar-benar dapat disebut sebagai raja yang mapan dan melembaga. Pasti Tuhan juga berkarya melalui lembaga yang mapan itu, tetapi campur tangan Tuhan secara langung (seperti pada zaman hakim-hakim) tidak begitu terasa lagi. Selain itu, bangsa Israel harus membayar harga yang mahal untuk kemapanan itu, seperti yang dikeluhkan oleh bangsa Israel tentang raja Salomo di hadapan anaknya Rehabeam: "Ayahmu telah memberatkan tanggungan kami" (1Raj. 12:4).

Hal yang sama juga dapat dilihat pada nubuatan Samuel tentang segi yang buruk dari pemerintahan raja yang mapan: "Anak-anakmu laki-laki akan diambilnya dan dipekerjakannya pada keretanya dan pada kudanya, dan mereka akan berlari di depan keretanya. ... mereka akan membajak ladangnya dan mengerjakan penuaian baginya; senjata-senjatanya dan perkakas keretanya akan dibuat mereka. Anak-anakmu perempuan akan diambilnya sebagai juru campur rempah-rempah, juru masak dan juru makanan. Selanjutnya dari ladangmu, kebun anggurmu dan kebun zaitunmu akan diambilnya yang paling baik dan akan diberikannya kepada pegawai-pegawainya; dari gandummu dan hasil kebun anggurmu akan diambilnya sepersepuluh dan akan diberikannya kepada pegawai- 
pegawai istananya dan kepada pegawai-pegawainya yang lain. Budak-budakmu laki-laki dan budak-budakmu perempuan, ternakmu yang terbaik dan keledai-keledaimu akan diambilnya dan dipakainya untuk pekerjaannya. Dari kambing dombamu akan diambilnya sepersepuluh, dan kamu sendiri akan menjadi budaknya”.

Kritikan seperti itu bahkan dapat dilontarkan kepada setiap negara dan pemerintah, entah dengan pola kepemimpinan demokratis, monarkis ataupun aristokratis. Karena pemerintah manapun yang melembaga pasti harus menarik pajak ataupun kerja rodi dari rakyat untuk membiayai tentara dan pegawainya. Hanya kepemimpinan karismatik para hakim dapat berjalan tanpa harus memungut pajak (karena tidak ada tentara profesional ataupun pegawai sipil), dan pada zaman hakim-hakim itu rakyat hanya berbakti kepada Tuhan, bukan kepada pemerintah. Ketidakmapanan pada zaman hakim-hakim itu membuat rakyat merasa semakin tergantung dari Tuhan dan kedahsyatan-Nya, tetapi membuat juga negara menjadi kurang stabil.

\section{Kesimpulan}

Dewasa ini masih muncul pemimpin karismatik di dunia politik. Kadang kala mereka memang dipilih dengan mekanisme lembaga demokrasi, seperti misalnya John F. Kennedy. Tetapi seringkali mereka tampil sebagai pemimpin karismatik terlebih dahulu, dan kemudian menjadi pemimpin terpilih, seperti misalnya Bung Karno, Mahatma Gandhi, dan Nelson Mandela. Orang beriman yakin bahwa pemimpin karismatik seperti itu memang dibangkitkan oleh Tuhan, seperti para hakim di Perjanjian Lama. Demikian pula Tuhan membangkitkan pemimpin karismatik di dunia kekristenan, seperti misalnya Martin Luther, Stephen Tong atau Petrus Agung. Seringkali mereka bangkit hanya berdasarkan karisma, bukan dengan melewati tangga karir institusional. Seyogyanya umat mensyukuri karya Tuhan yang membangkitkan pemimpin karismatik seperti itu, dan sebaiknya umat jangan hanya mengidolakan tokoh karismatik itu. Namun, ketika pemimpin karismatik seperti itu meninggal seringkali terjadi krisis, seperti yang dialami bangsa Israel pada masa hakim-hakim. Asisten terdekatpun sulit untuk menggantikan pemimpin karismatik itu, atau mereka bahkan memperebutkan posisi pemimpin di antara asisten-asisten itu.

Dalam krisis seperti itu, kepemimpinan karismatik perlu dilengkapi dengan kepemimpinan yang melembaga, dengan mekanisme pergantian pemimpin yang jelas dan dengan prinsip: Daripada tidak ada pemimpin sama sekali, lebih baik ada pemimpin meskipun kurang berkarisma. Di bawah kepemimpinan karismatik, banyak hal yang dapat 
diatur secara spontan, tanpa aparat birokrasi yang rumit dan mahal. Tetapi ketika tidak ada pemimpin karismatik, aparat birokrasi seperti itu sangat diperlukan, dan umat harus siap membayar harganya. Seringkali karya Tuhan terasa sangat langsung di bawah pemimpin karismatik. Namun, umat juga harus siap menyadari karya Tuhan melalui struktur lembaga. Dengan demikian pola kepemimpinan karismatik pada zaman hakim-hakim tetap dapat menjadi contoh dewasa ini, demikian juga terhadap pola kepemimpinan yang melembaga pada zaman raja-raja dapat diambil segi baiknya-baik di gereja maupun di masyarakat. Tuhan berkarya melalui kedua-duanya.

\section{Kepustakaan}

Payne, J. P. Art. "Book of Judges". Dalam: Marshall, I. Howard; Millard, A. R.; Packer, J. I.; Wiseman, D. J. (eds.). New Bible Dictionary (3rd ed.). Leicester, England: Inter-Varsity Press, 1996.

Pixley, George V. Kerajaan Allah. Artinya bagi Kehidupan Kultus, Politis, Ideologis dan Kemasyarakatan. Jakarta: BPK, 1990.

Zwingenberger, Uta. Art. „Eisenzeit I“ <bhs. Jerman: Zaman Besi I >, dalam: WibiLex Wissenschaftliche Bibellexikon im Internet <bhs. Jerman: Leksikon Alkitab di Internet>, ditulis Febr. 2007, diakses 30 Okt. 2019 (https://www.bibelwissenschaft.de/stichwort/17088/) 